Article

\title{
The Microbiota of Edam Cheeses Determined by Cultivation and High-Throughput Sequencing of the 16S rRNA Amplicon
}

\author{
Beata Nalepa $^{1, *}$, Sławomir Ciesielski ${ }^{2}$ (D) and Marek Aljewicz ${ }^{3}$ (1) \\ 1 Department of Industrial and Food Microbiology, Faculty of Food Science, University of Warmia and \\ Mazury in Olsztyn, Pl. Cieszyński 1, 10-726 Olsztyn, Poland \\ 2 Department of Environmental Biotechnology, Faculty of Geoengineering, University of Warmia and Mazury \\ in Olsztyn, ul. Słoneczna 45G, 10-719 Olsztyn, Poland; slawomir.ciesielski@uwm.edu.pl \\ 3 Department of Dairy Science and Quality Management, Faculty of Food Science, University of Warmia and \\ Mazury in Olsztyn, ul. Oczapowskiego 7, 10-719 Olsztyn, Poland; marek.aljewicz@uwm.edu.pl \\ * Correspondence: beata.nalepa@uwm.edu.pl; Tel.: +48-8-9523-4995
}

Received: 4 May 2020; Accepted: 10 June 2020; Published: 12 June 2020

\begin{abstract}
The aim of this study was to evaluate the microbiome of industrially produced ripened Edam cheeses by next-generation sequencing. The samples for analyses were collected in spring and autumn. Spring samples were characterized by significantly higher Lactococcus and Bacillus counts and lower counts of Enterobacteriaceae, Enterococcus, and yeasts than autumn samples. The predominant microorganisms identified by the Illumina high-throughput sequencing technology belonged to four phyla: Firmicutes, Actinobacteria, Proteobacteria and Bacteroidetes. The dominant species were starter culture bacteria. Lactobacillus rhamnosus, Lactobacillus kefiri, Lactobacillus kefiranofaciens, Lactobacillus casei, Streptococcus thermophilus, and Bifidobacterium had the highest share of microbial cheese communities. The number of $\gamma$-Proteobacteria reads was higher in autumn cheese samples. A high number of reads was also noted in the genus Clostridium. The counts of spore-forming bacteria of the genus Bacillus were higher in cheeses produced in spring. The study revealed highly similar relationships between the analyzed production periods. The present results contribute to the existing knowledge of cheese microbiota, and they can be used to improve and modify production processes based on the composition of microbial communities, as well as to improve the quality of the final product.
\end{abstract}

Keywords: microbiota; seasonal variations; high-throughput sequencing; NGS

\section{Introduction}

The quality of fermented foods is determined mostly by microbial genera and species colonizing food products. The above applies to all processing stages, from the raw material to the final product [1-3]. Microorganisms are ubiquitous in the farm environment (soil, water, feed, natural fertilizers, and premises). They are also present on animal skin, in animal digestive tracts, and in animal secretions (such as milk), and they colonize the surface of fodder plants. Microorganisms are found on the surface of processing lines, devices, machines, conveyor belts, pipelines, packaging, and auxiliary raw materials. They are added to products as starter cultures, and they are present on the hands of dairy plant employees [4,5]. Microorganisms spread from the above sources to raw materials and end products, and they influence the attributes of fermented foods. Therefore, cheese microbiota constitute one of the critical factors during cheese ripening and the formation of the sensory properties of cheese. The formation of sensory attributes is a complex biochemical process where environmental and process conditions, such as the heating temperature of the cheese slurry and the 
time and temperature of cheese ripening, affect the composition and metabolic activity of microbiota [6]. Microbial communities colonizing fermented foods are highly complex, and they have not been thoroughly investigated to date [1-3]. Many microbial species cannot be cultured in vitro on standard microbiological media, which prevents their identification. Some microorganisms are weakened or sublethally damaged by processing operations, and they enter the viable but not culturable (VBNC) state [7]. Other microorganisms cannot be identified with the use of culture-dependent methods due to their small population size and the overwhelming effect of predominant species, such as starter culture bacteria. A knowledge of the biodiversity of bacterial communities in fermented foods is highly valuable because every microbial species, including low-abundance species, contribute specific enzymes, metabolites, bacteriocins, and genetic material to the metabiome. A better understanding of the interactions between microorganisms, their metabolites, the effects of process parameters, external factors, and disruptions in the production cycle can expand our knowledge of specific microbial communities. This knowledge can be used to develop new tools for designing the most desirable attributes of fermented foods and to precisely control the production process to achieve the desired effects. Considerable advances have been made in molecular analysis since the late 1980s, and they have led to the development of the PCR technique by Kary Mullis in 1983 [8], which supports analyses of the complex ecosystems of fermented foods. Technological progress introduced molecular biology methods to traditional food microbiology. The last decade witnessed the emergence of new methods such as next-generation sequencing (NGS) and new research fields such as metagenomics and metatranscriptomics [9]. Modern NGS techniques support the high-throughput sequencing of genes, metagenomes, and metatranscriptomes, and they deliver new insights into the diversity and metabolic properties of fermented food microbiota, including the microbiota of ripened cheese [10]. The resulting data add to current knowledge about the interactions between microorganisms, the environment, and other microorganisms, and they support the development of strategies for improving the production process and cheese quality. In recent years, metagenomic and/or metatranscriptomic analyses have been conducted on samples of regional cheeses, including water buffalo mozzarella cheese [11], Belgian Herve cheese [12], Italian Plaisentif, Mozzarella, Grana Padano and Parmigiano Reggiano cheese [13,14], Mexican Cotija cheese [15], and French Tomme d'Orchies Livarot-type cheese [16,17], as well as industrially produced Dutch-type [18] and Swiss-type cheese [19]. The microbiological quality of ripened cheese has been widely researched in the literature [20-22]. However, the formerly applied analytical methods have failed to provide comprehensive information about the microbiome of ripened cheese. Recent advances in molecular biology can be deployed to fill this knowledge gap. Therefore, the aim of this study was to determine the microbiota of Edam cheeses produced industrially in Poland with the use of the Illumina technology.

\section{Materials and Methods}

\subsection{Cheese Sampling}

The study was performed on Swiss-Dutch-type (Edam) cheeses manufactured by a dairy plant in north-eastern Poland. Raw milk for cheese production was pasteurized $\left(72.5^{\circ} \mathrm{C}\right.$ for $\left.15 \mathrm{~s}\right)$ and standardized (to $3.0 \%$ fat content). Calcium chloride, a coloring agent, and rennet (Chymax, Ch. Hansen, Poland) were added, and milk was inoculated with deep-frozen cheese starters (CSK Food Enrichment, Poland). Milk was inoculated with $0.7 \%$ (v/v) of the lactic acid bacterial starter (Lactococcus lactis subsp. lactis, Leuconostoc mesenteroides subsp. cremoris) and $0.007 \%(v / v)$ of the propionic acid bacterial starter (Propionibacterium freudenreichii subsp. shermanii). After brining, cheeses were wrapped in FCC-type (Fesco Pack, Malbork, Poland) heat shrink oxygen barrier bags and cold-stored under controlled conditions. The cheeses were ripened for 10 days at $12{ }^{\circ} \mathrm{C}$ and a relative humidity of $85 \%$. After 10 days, the ripening temperature was increased to $21^{\circ} \mathrm{C}$ for 42 days. After 52 days of ripening, cheese samples were randomly collected for analysis. Three random cheese samples were collected each month. The representative cheeses were sampled in compliance with ISO 707:2008 [23]. Before the 
experiment, the samples collected over one month (April or October) were grated with a Santos 2 grater (Lyon, France) and combined with the samples collected in the following month (May or November, respectively) of the same season. All cheeses were sampled over a period of 2 years. The resulting averaged sample was used for further analysis. Cheeses produced in April-May were regarded as spring samples, and cheeses produced in October-November were regarded as autumn samples.

\subsection{Chemical Composition}

Cheese samples were analyzed in triplicate to determine their salt content by the IDF method (IDF 88; ISO 5943:2006) [24], fat content was determined by the Van Gulik method (IDF 222, ISO 3433:2008) [25], and moisture content was determined by oven drying at $102{ }^{\circ} \mathrm{C}$ (AOAC 926.08) [26].

\subsection{Determination of the Counts of Selected Bacterial Groups by the Culture-Dependent Method}

The counts of bacteria of the genera Lactobacillus, Lactococcus, Leuconostoc, Propionibacterium, Enterobacteriaceae, Enterococcus, Staphylococcus, Clostridium, and Bacillus, as well as yeasts, were determined by the standard plate count method on the appropriate culture media. The applied culture media and incubation conditions are presented in Table 1.

Table 1. Culture media and incubation conditions applied in the study.

\begin{tabular}{lll}
\hline Microorganism & Medium & Incubation Conditions \\
\hline Lactobacillus spp. & MRS agar (Merck) & $37^{\circ} \mathrm{C}, 48 \mathrm{~h}$, anaerobic incubation \\
\hline Lactococcus spp. & M17 agar (Merck) & $30{ }^{\circ} \mathrm{C}, 48 \mathrm{~h}$ \\
\hline Leuconostoc spp. & $\begin{array}{l}\text { Sucrose agar: } \\
\text { (sucrose-50 g/L; yeast extract-10 g/L; agar-15 } \\
\text { g/L; pH 7.2-7.4) }\end{array}$ & $30{ }^{\circ} \mathrm{C}, 72 \mathrm{~h}$ \\
\hline Propionibacterium spp. & $\begin{array}{l}\text { Lactate agar: } \\
\text { lpeptone-10 g/L; yeast extract-5 g/L; calcium }-10 \mathrm{~g} / \mathrm{L} ; \text { agar-15 g/L; } \mathrm{pH} 7.0-7.2)\end{array}$ & $\begin{array}{l}3{ }^{\circ} \mathrm{C}, 72-96 \mathrm{~h} \text {, anaerobic } \\
\text { lactabation }\end{array}$ \\
\hline Enterobacteriaceae & VRBG (Merck) & $37^{\circ} \mathrm{C}, 24-48 \mathrm{~h}$ \\
\hline Enterococcus spp. & Slanetz-Bartley agar (Merck) & $37^{\circ} \mathrm{C}, 48 \mathrm{~h}$ \\
\hline Staphylococcus spp. & RPF agar (Merck) & $37^{\circ} \mathrm{C}, 48 \mathrm{~h}$ \\
\hline Clostridium spp. & RCM agar (Oxoid) & $37^{\circ} \mathrm{C}, 48 \mathrm{~h}$, anaerobic incubation \\
\hline Bacillus spp. & Nutrient agar (Merck) & $30^{\circ} \mathrm{C}, 48 \mathrm{~h}$ \\
\hline Yeasts and molds & YGC agar (Merck) & $25^{\circ} \mathrm{C}, 72-96 \mathrm{~h}$ \\
\hline
\end{tabular}

\subsection{DNA Isolation}

Metagenomic DNA was directly isolated from cheese samples with the use of the Genomic Mini AX FOOD kit (A@A Biotechnology, Gdańsk, Poland) according to the manufacturer's instructions, and it was stored at $-80{ }^{\circ} \mathrm{C}$ until further analyses.

\subsection{Amplicon Sequencing and Bioinformatics Analysis}

The microbial communities colonizing the analyzed samples were examined by the sequencing of the V3-V4 region of the 16S rRNA gene. The 16S rRNA gene fragment was amplified with the PCR primers recommended for the Illumina technique. The primers were developed by adding Illumina adapter overhang nucleotide sequences to the PCR primers given by Klindworth et al. [27]. Amplicons were indexed using the Nextera ${ }^{\circledR}$ XT Index Kit (Illumina, Inc. San Diego, CA, United States) according to the manufacturer's instructions. DNA was sequenced in Illumina MiSeq in the $2 \times 250$ paired-end mode. Demultiplexing and FASTQ file generation were performed using Miseq Reporter v.2.4. (Illumina, Inc. San Diego, CA, United States). 
Sequencing results in the form of FASTQ files were uploaded to the MetaGenome Rapid Annotation Subsystems Technology (MG-RAST) server for analysis [28]. Each file underwent quality control (QC), which included quality filtering (removing sequences with $\geq 5$ ambiguous base pairs) and length filtering (removing sequences with a length $\geq 2$ standard deviations from the mean). The UCLUST algorithm was used to cluster the identified rRNA sequences. A representative sequence of each cluster was used for taxonomic identification based on the Greengenes reference database. Illumina metagenomic datasets are available at MG-RAST under accession numbers 4,730,840.3, 4,730,841.3, 4,730,842.3, and $4,734,160.3$. Additionally, sequencing data were deposited in the Sequence Read Archive (SRA) NCBI (https://www.ncbi.nlm.nih.gov/) as a Bioproject under the accession code: PRJNA637891.

\subsection{Statistical Analysis}

The results of chemical composition analysis and bacterial counts were verified for normal distribution and homogeneity of variance. The interactions between production seasons were determined by a one-way ANOVA. The results were statistically analyzed with the Statistica software (Statsoft; 2018, Kraków, Poland) at $p \leq 0.05$. All data (microbiological and physicochemical parameters) are presented as means \pm standard deviation.

\section{Results and Discussion}

\subsection{Chemical Composition}

The analyzed cheeses did not significantly differ in water content. The average water, fat, and sodium chloride content of all samples were determined at $42 \%, 27 \%$, and $1.5 \%$, respectively (Table 2). The production period had no significant effect on the composition of the cheeses. The absence of significant differences between the cheeses could be attributed to adequate standardization of the raw material and the use of more automated production lines.

Table 2. Chemical composition of Edam cheeses *.

\begin{tabular}{ccc}
\hline Composition [\%] & \multicolumn{2}{c}{ Season } \\
\cline { 2 - 3 } & Autumn & Spring \\
\cline { 2 - 3 } water & $42.50 \pm 0.87$ & $42.20 \pm 0.77$ \\
fat & $27.51 \pm 0.38$ & $27.19 \pm 1.26$ \\
sodium chloride & $1.49 \pm 0.07$ & $1.51 \pm 0.06$ \\
\hline
\end{tabular}

* The results are expressed as means \pm standard deviation; $n=3$. The analyses were conducted after 52 days of cheese ripening.

\subsection{Determination of the Counts of Selected Bacterial Groups by the Culture-Dependent Method}

The abundance of the selected bacterial groups was determined by the traditional culture-dependent method. The applied culture media are presented in Table 3. The microbiological quality of cheese depends on climatic conditions, cow health, cow nutrition, lactation period, and the type and number of starters. Despite the standardization of raw materials and the automation of cheese production, even the same types of cheese sampled from various vats can differ in microbiological quality.

The addition of a starter culture was responsible for the high counts of Lactococcus, Leuconostoc, and Propionibacterium. The statistical analysis revealed that Lactococcus counts were significantly influenced by the production season $(p \leq 0.05)$, and the average Lactococcus counts in autumn cheeses were determined at $\log 6.55 \mathrm{cfu} / \mathrm{g}$ and were lower than in spring cheeses $(\log 7.16 \mathrm{cfu} / \mathrm{g})$. Cheeses produced with Lactococcus starter cultures were characterized by high Lactococcus counts. In turn, high Lactococcus counts in mature cheeses were attributed to the availability of suitable carbon and nitrogen energy sources, including bacterial metabolites (low-molecular-weight peptides, free amino acids, citrate, RNA (ribose), and DNA (deoxyribose) produced during starter lactic acid bacteria (SLAB) 
lysis. Similar results have been reported by other authors [29-31]. Season had no significant effect on Leuconostoc and Propionibacterium counts, which were determined at 4.43 and $5.75 \mathrm{cfu} / \mathrm{g}$ on average, respectively (Table 3). Interestingly, Lactobacillus counts were around $11 \%(p>0.05)$ higher in the spring cheese than in the autumn cheese samples. Due to seasonal changes in the microbiological quality of the raw material, some dairies add larger amounts of starter cultures to cheese vats to accelerate ripening and obtain cheeses with desirable sensory attributes. The presence of higher Lactococcus and Propionibacterium counts in the spring cheeses seems to confirm the above observation. During ripening, starter cultures undergo autolysis, which leads to the release of cell wall elements and nucleic acids. These compounds are used by bacteria, including Lactobacillus strains, as a source of carbon or nitrogen. Similarly to Lactobacillus, Enterococcus strains are also classified as non-starter lactic acid bacteria (NSLAB). The high Enterococcus counts in mature cheeses could be explained by the fact that Enterococcus spp. are highly resistant to pasteurization temperature and that milk fat exerts protective effects [32]. The counts of Enterococcus and Enterobacteriaceae were significantly influenced by season. The average counts of Enterococcus and Enterobacteriaceae reached 3.63 and $2.50 \mathrm{cfu} / \mathrm{g}$, respectively, and were higher (log 0.50 and $\log 0.86 \mathrm{cfu} / \mathrm{g}$, respectively) in cheeses produced in spring. Enterococcus counts were similar to those reported by other authors in Swiss-type cheese (2-3 cfu/g) [29], but they were significantly lower than in Spanish cheese (6-8 log cfu/g) [33]. The low Enterobacteriaceae counts could probably be attributed to the fermenting activity of Lactic Acid Bacteria (LAB) and the synthesis of antibacterial compounds (bacteriocins, organic acids, ethanol, and $\mathrm{H}_{2} \mathrm{O}_{2}$ ) that reduce microbial counts by increasing the permeability of bacterial cell walls [29,30]. The lower counts of Enterococcus and Enterobacteriaceae in autumn cheeses could also indicate that hygiene standards are strictly observed by dairy employees.

Table 3. Counts of selected microbial groups in Edam cheeses determined by the culture-dependent method.

\begin{tabular}{ccc}
\hline \multirow{2}{*}{ Bacteria } & \multicolumn{2}{c}{ Season } \\
\cline { 2 - 3 } & Autumn & Spring \\
\hline Lactococcus & $6.55 \pm 0.25^{\mathrm{b}, *}$ & $7.16 \pm 0.33^{\mathrm{a}}$ \\
Leuconostoc & $4.60 \pm 0.99$ & $4.25 \pm 0.86$ \\
Propionibacterium & $5.64 \pm 0.53$ & $5.85 \pm 0.12$ \\
Lactobacillus & $5.97 \pm 0.55$ & $6.64 \pm 0.51$ \\
Enterobacteriaceae & $2.50 \pm 0.55^{\mathrm{a}}$ & $2.00 \pm 0.01^{\mathrm{b}}$ \\
Enterococcus & $3.63 \pm 0.36^{\mathrm{a}}$ & $2.77 \pm 0.85^{\mathrm{b}}$ \\
Staphylococcus & $3.00 \pm 0.24$ & $2.70 \pm 0.79$ \\
Clostridium & $4.32 \pm 0.40^{\mathrm{b}}$ & $3.87 \pm 1.15$ \\
Bacillus & $3.35 \pm 0.66^{\mathrm{b}}$ & $4.53 \pm 0.47^{\mathrm{a}}$ \\
Yeasts & $2.83 \pm 0.26^{\mathrm{a}}$ & $2.00 \pm 0.01^{\mathrm{b}}$ \\
\hline
\end{tabular}

*Values are means \pm standard deviation for $n=6,{ }^{\text {a,b }}$ Means in rows with different superscript letters are significantly different $(p \leq 0.05)$.

Yeast counts were below $\log 2 \mathrm{cfu} / \mathrm{g}$ in spring cheeses, and they were significantly lower in autumn cheeses $(\log 2.82 \mathrm{cfu} / \mathrm{g})$. The observed yeast counts were below the values given by other authors in Swiss-type cheese (3.48 cfu/g) [29], Gouda-type cheese $(3.22-50 \mathrm{cfu} / \mathrm{g})$ [29,31], Chihuahua cheese (5 cfu/g) [34], and Serrano cheese (4-4.5 cfu/g) [30]. Similar results were reported by Sánchez-Gamboa et al. [34]; in their study, yeast counts were $50 \%$ higher in cheeses produced in autumn. Different results were reported by de Souza et al., [30]. Higher yeast counts in autumn cheeses probably resulted from the low microbiological quality of brine or cheese contamination during packaging.

Autumn cheeses are made from the milk of pasture-grazed cows, which is why Clostridium counts in autumn cheeses should have been lower than in spring cheeses. Despite the above, Clostridium counts were approximately $10 \%(p>0.05)$ higher in autumn cheeses than in spring cheeses. In a 
study by Bermúdez et al. [35], Clostridium counts were also approximately $9 \%$ higher in autumn than in spring cheeses. In recent years, many milk producers have been increasing the proportions of silage in the diets of lactating cows to maximize milk yields and to allow for greater flexibility in managing cattle diets. Such practices contribute to the accumulation of Clostridium spores in the bovine digestive tract. Bacterial spores can be transferred to milk during milking, especially if teats are not properly cleaned [35]. Lower Clostridium counts in autumn cheeses probably result from higher levels of bacteriocin synthesis by LAB (mainly: Lactococcus, Propionibacterium, and Lactobacillus) [36].

\subsection{Determination of the Microbiota of Edam Cheeses by High-Throughput Sequencing (HTS)}

The number of $16 \mathrm{~S}$ rRNA sequence reads ranged from 332,280 to 436,468 in cheese samples after 52 days of ripening. The predominant microbial groups belonged to four phyla: Firmicutes, Actinobacteria, Proteobacteria, and Bacteroidetes (Figure 1).

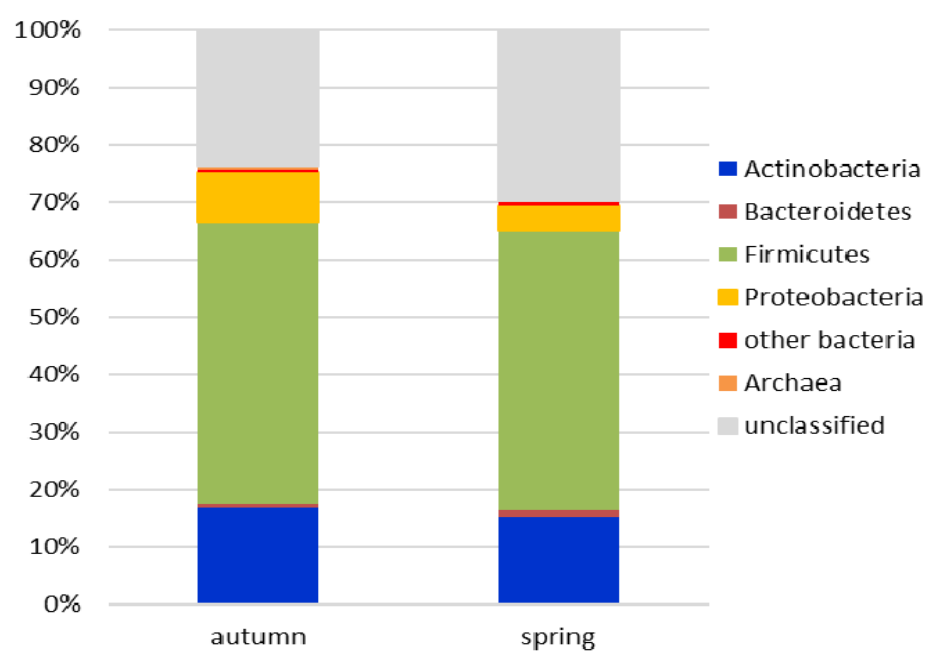

Figure 1. The average relative abundance (\%) of the sequences identified at phylum level in samples of Edam cheese.

Eleven predominant genera were identified in the group of 32 genera and taxonomic groups that accounted for at least $0.5 \%$ of the bacterial community. They were: Acetobacter, Alcaliphilus, Bacillus, Bacteroides, Bifidobacterium, Cellulomonas, Clostridium, Lactococcus, Lactobacillus, Leucobacter, Propionibacterium, and one group of $\gamma$-Proteobacteria. Similar results were reported in a study of Oscypek, a traditional Polish smoked cheese made of sheep's milk [37]. The authors demonstrated the predominance of the same four phyla and identified nine identical genera and taxonomic groups in 40 operational taxonomic units (OTUs). The proportions of the remaining genera were below $0.5 \%$, and not all genera were identified in all samples. The average bacterial identification levels were similar $(75-70 \%)$ in the spring and autumn seasons. In autumn and spring samples, $25 \%$ and $30 \%$ of the sequences could not be identified, respectively. The genera represented by dozens or hundreds of reads, including Archaea and algae (Eukaryota), accounted for a large part of the taxonomic spectrum in cheese samples. A high number of DNA sequences were not classified in the remaining cheese samples (Figure 1). The above could be attributed to the presence of microorganisms that have not yet been classified or microorganisms containing degraded DNA. Fernandes et al. [38] observed that DNA was degraded to very short fragments during corn dough fermentation. The content of bacterial proteases, proteinases, and peptidases increases gradually during cheese ripening and storage. Similarly to bacterial proteases, DNA-degrading enzymes (nucleases) can also be released into the cheese matrix during the autolysis of starter and non-starter lactic acid bacteria [39], or they can be bacteriophage-derived [19].

The highest number of reads was obtained for two out of the three genera of starter bacteria: Lactococcus and Propionibacterium. In the analyzed group of the SLAB, Lactococcus was the predominant 
genus in the phylum Firmicutes, and it accounted for $43.78 \%$ and $53.35 \%$ of the microbial communities in autumn and spring cheese samples, respectively. The second most dominant starter culture belonged to the genus Propionibacterium, phylum Actinobacteria. Propionibacterium counts were lower, and they were determined at $9.41 \%$ and $12.37 \%$ in spring and autumn cheese samples, respectively. A comparison of the number of reads for the selected bacterial genera revealed important differences, including in starter bacteria that are added in strictly controlled amounts to every cheese batch. The number of reads for the third genus of starter bacteria, Leuconostoc, was very low at a fraction of a percent (Figure 2 and Table S1). The analyzed cheeses were characterized by highly diverse microbiota. Starter bacteria develop in the first stages of the production process and dominate over residual microflora and the microorganisms from secondary infections. During ripening, bacterial starter cells are gradually autolyzed, which promotes the growth of non-starter bacteria that can also influence the attributes of the final product [40]. For this reason, the microbiota of ripened cheese are more diverse than those observed immediately after production or short ripening. Alessandria et al. [41] demonstrated that the microbiota of Grana-like cheese begin to diversify upon brining and undergo significant changes during two months of ripening. In the present study, starter bacteria were predominant in the Edam cheese. Lactococcus and Propionibacterium from starter cultures accounted for 56-65\% of all bacteria, whereas Leuconostoc represented only a fraction of percent of the overall microbial community. Similar results were reported by Almeida et al. [42]; in their study, the number of sequence reads for Leuconostoc was also low. A predominance of starter bacteria was reported by Ceugniez et al. [16], who found that starter bacteria accounted for $85 \%$ of the microbiota in the core samples of Tomme d'Orchies cheese, and by Alessandria et al. [41], who demonstrated that Lactobacillus and Streptococcus predominated in Grana-like cheese inoculated with natural whey starters (NWS). Duru et al. [19] also found that Lactococcus, Lactobacillus, and Propionibacterium bacteria accounted for $80-82 \%$ of the microbiota in industrially produced Swiss cheese. However, in a study by Porcelato et al. [18], starter bacteria (Lactococcus, Leuconostoc, and Lactobacillus) represented more than $99 \%$ of the bacterial community in industrially produced Dutch cheese.

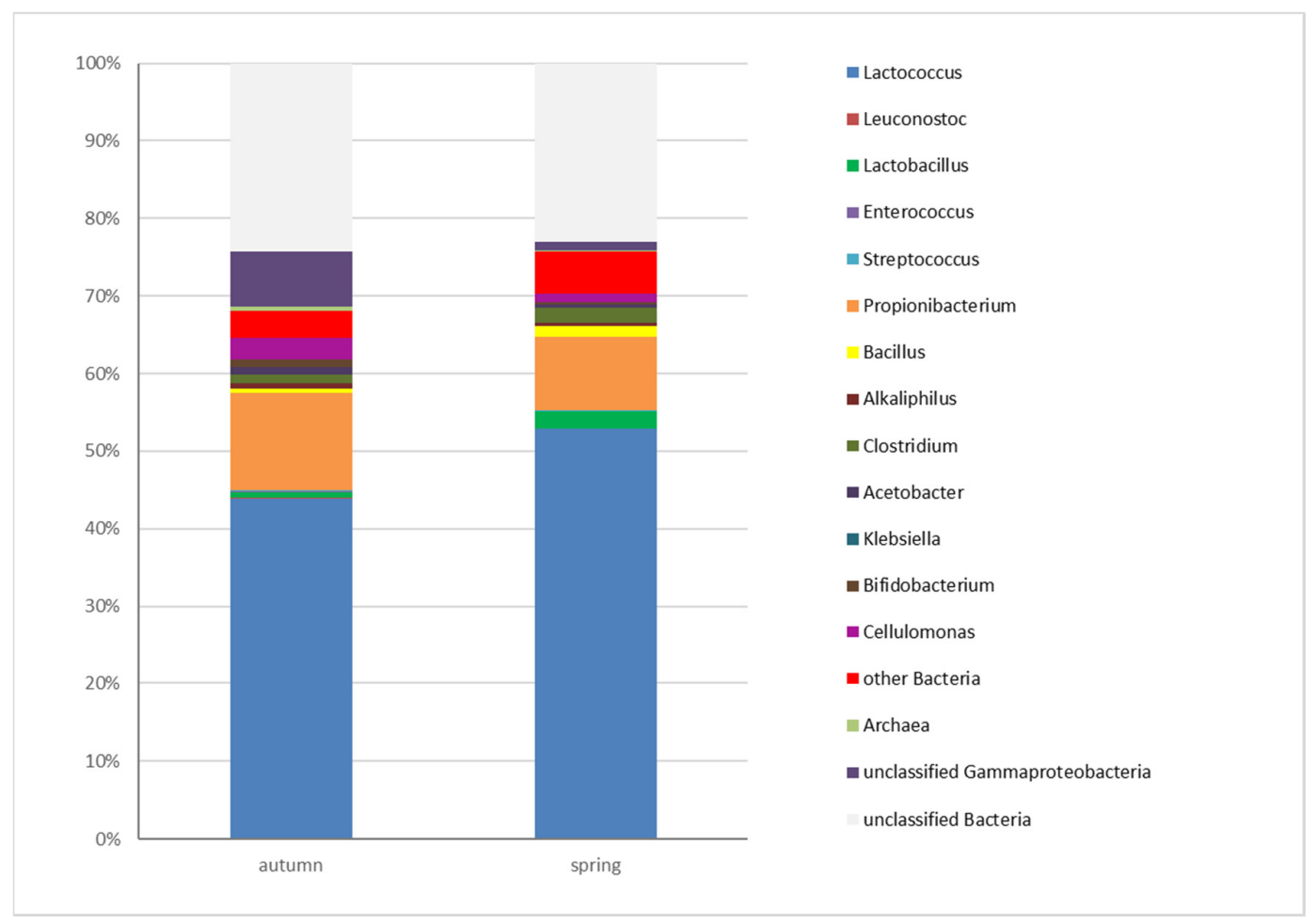

Figure 2. The average relative abundance (\%) of the sequences identified at genus level in samples of Edam cheese. 
The results of the SLAB and NSLAB analyses performed with the use of both methods (culture-dependent and NGS) revealed a certain regularity. When plate counts (expressed in $\log \mathrm{cfu} / \mathrm{g}$ ) were one log unit higher in one bacterial genus than in another, the corresponding number of reads was approximately 10 times higher (Table 3 and Table S1).

Despite the high proportions of starter bacteria in cheese samples, a high number of reads was noted for the NSLAB. In the phylum Actinobacteria, the abundance of Cellulomonas in the microbial community was relatively high, and it ranged from $1 \%$ to $3 \%$ in all cheese samples. The genera Bifidobacterium and Leucobacter were less abundant, and their proportions were determined at $0.40 \% / 0.94 \%$ and $0.18 \% / 0.33 \%$, respectively. The remaining identified genera of the phylum Actinobacteria accounted for up to $0.2 \%$ of the investigated microbial communities (Table S1). Spring cheese samples differed considerably from the remaining samples in the frequency of Lactobacillus, which was higher in spring samples (approximately 1.5\%) (Table S1). In the genus Lactobacillus, the highest number of reads was obtained for Lactobacillus rhamnosus, Lactobacillus kefiri, Lactobacillus kefiranofaciens, and Lactobacillus casei (data not shown). The relative frequency of Bifidobacterium and Streptococcus was $0.6 \%$ and $0.3 \%$ higher, respectively, only in individual samples relative to the remaining cheese samples $(0.08 \%)$ (data not shown). Similar results were reported in other studies of industrially produced cheeses. Porcelato et al. [18] detected Lactobacillus and Streptococcus in Dutch-type cheese, and Duru et al. [19] identified Enterococcus and Streptococcus in Swiss-type cheese.

The phylum Firmicutes also includes bacteria that cause technological defects in cheeses. In the group of contaminating bacteria, the highest number of reads was obtained for spore-forming bacteria of the genus Clostridium. The relative proportions of Clostridium were $0.97 \%$ higher in spring samples than in autumn samples. The genus Clostridium was represented mainly by three species: Clostridium butyricum, Clostridium longisporum, and Clostridium tyrobutyricum. In spring samples with the highest number of reads for the genus Clostridium, the predominant species was C. tyrobutyricum, whose abundance was around 10-fold higher in comparison with C. butyricum and C. longisporum in the remaining samples (data not shown). In the current study, next-generation sequencing supported the detection of $C$. tyrobutyricum, which could be responsible for late blowing, a cheese defect resulting from butyric acid fermentation [43,44]. This is a very valuable observation that can be used to introduce the required adjustments during cheese production, ripening, and storage. Spore-forming bacteria of the genus Bacillus also had a relatively high share of microbial communities, particularly in spring samples where the average frequency of Bacillus was $0.81 \%$ higher than in autumn samples. The proportions of spore-forming bacteria of the genus Bacillus were higher in spring cheeses than in autumn cheeses. The observed variations can be probably attributed to dietary factors because cows graze naturally on grass in summer and autumn. Henderson et al. [45] demonstrated that the abundance of bacterial genera in the bovine rumen changed with the cows' diet. The presence of bacteria in milk can also differ because raw milk microbiota are much more diverse and contain more environmental bacteria and microorganisms from the bovine digestive tract in summer and autumn. In winter and spring, cows are fed with hay and silage, which increases the counts of spore-forming bacteria of the genus Bacillus in the environment, milk, and, consequently, cheese. The autumn samples were characterized by the greatest differences in the frequency of Enterococcus spp. $(0.06 \%)$, and they differed $(p>0.05)$ from spring samples (Table S1). The analyzed cheeses also contained trace amounts of DNA of the microorganisms colonizing the natural environment and cows. The remaining identified bacterial genera of the phylum Firmicutes accounted for up to $0.2 \%$ of the analyzed microbial communities. On rare occasions, selected genera, including Veillonella, Laceyella, Streptococcus, Eubacterium, and Ruminococcus, were more abundant (Table S1). Bacteria of the phylum Proteobacteria accounted for $3.26 \%$ (spring samples) and $8.69 \%$ (autumns samples) of microbial communities. They were mostly represented by members of the class $\gamma$-Proteobacteria whose DNA sequences could not be identified to the genus level. The proportion of $\gamma$-Proteobacteria ranged from $1.11 \%$ in spring samples to $7.11 \%$ in autumn samples (Figure 2 and Table S1). Among the identified genera, the predominant class was $\alpha$-Proteobacteria of the genus Acetobacter, which accounted for $0.39-1.01 \%$ of microbial communities in 
spring and autumn samples, respectively. The class $\gamma$-Proteobacteria of the genus Acinetobacter was also abundantly represented in spring samples at $1.56 \%$ (Table S1). The phylum Bacteroidetes accounted for $0.52-0.84 \%$ of microbial communities in the analyzed cheese samples, and it was represented mostly by the genus Bacteroides, whose abundance ranged from $0.15 \%$ in spring samples to $0.30 \%$ in autumn cheese samples. Other genera were sporadically noted, including Prevotella and Chryseobacterium (Table S1). Cheeses were also colonized by bacteria of the genera Acinetobacter, Chryseobacterium, and Alkaliphylus which are ubiquitous in soil and water, as well as Cellulomonas, Eubacterium, Rothia, and Ruminococcus, which are found in the bovine digestive tract $[11,13,41]$. Interestingly, the unexpected bacterial genera Alloscardovia, Prevotella and Veillonella from animal respiratory and digestive systems [45,46] —as well as Laceyella, which are found in bottom sediments, soil, and patients with farmer's lung disease [47]—were also identified at relatively high concentrations in individual samples. The DNA of Erysipelothrix rhusiopathiae, a bacterium responsible for swine erysipelas disease [48], was detected in a single sample in our study. The proportion of this bacterium in the sample was surprisingly high at $0.22 \%$, which can probably be attributed to the accidental contamination of raw milk by veterinarians or farm personnel. Bokulich and Mills [49] also identified various bacterial and fungal genera that were not added as starter cultures. The presence of the DNA of unexpected bacterial genera and species provides detailed information about the quality of raw milk, and it can be used to prevent contamination of milk and the final product.

In the present study, the variations in bacterial genera colonizing the evaluated samples were very high, despite the fact that all samples were obtained from the same dairy plant, and the raw milk was produced in the same Polish region. Alessandria et al. [41] also found differences in the composition of microbial populations colonizing cheeses from the same dairy plant. They observed considerable microbial diversity of cheeses produced in spring at weekly intervals. The above could imply that minor fluctuations in the production process significantly influence the composition of cheese microbiota. Differences in microbiological quality can also result from various stages of cheese ripening, variations in the microbial composition of raw milk, environmental factors, other disruptive factors, and minor deviations from production procedures. In this study, certain seasonal changes in cheese microbiota were also noted, though only in communities of contaminating microorganisms.

\section{Conclusions}

High levels of milk production in dairies and the combination of raw materials from different milk producers (different regions of the country) contribute to the high microbial biodiversity of cheese and the absence of significant differences in the OTU reads across production seasons. This study demonstrated that despite the application of different testing techniques, the relationships between the analyzed production periods were highly similar. Both next-generation sequencing and culture-dependent approaches are sources of bias, but they provide complementary information about the microbial ecology of cheese. The evaluated Edam cheeses were characterized by a predominance of starter bacteria and the presence of non-starter lactic acid bacteria from the microflora of the dairy plant and the cattle environment. Trace amounts of bacteria that are pathogenic for cattle were also identified. High-throughput sequencing also supported the identification of low-abundance bacteria, as well as bacteria that had not been previously detected in ripened cheeses. Advanced analytical tools developed by "omics" sciences can provide new insights into the metagenomes of fermented foods, including ripened cheeses. Metagenomic profiling has created unprecedented opportunities for analyzing cheese ecology. The identification of the genes and genomes of microbial communities in ripened cheeses supports the detection of the most desirable strains, the description of their development and transfer, and the identification of microbial contaminants and pathogens.

Supplementary Materials: The following are available online at http://www.mdpi.com/2076-3417/10/12/4063/s1, Table S1: Percentages of the most abundant taxonomic groups in Edam cheese samples after 52 days of ripening.

Author Contributions: B.N. developed the research concept and administered the research project. B.N., S.C., and M.A. procured the materials, developed the methodology, analyzed and curated the data, performed formal 
analyses, and wrote the manuscript. B.N. and M.A. acquired research funds, visualized data, and reviewed and edited the manuscript. All authors have read and agreed to the published version of the manuscript.

Funding: The project was financially supported by the Minister of Science and Higher Education under the program entitled “Regional Initiative of Excellence" for the years 2019-2022, Project No. 010/RID/2018/19, amount of funding PLN 12,000,000 and by University of Warmia and Mazury in Olsztyn (statutory research, Projects No. 17.610.015-300 and 17.610.003-110).

Conflicts of Interest: The authors declare no conflict of interest.

\section{References}

1. Ogier, J.-C.; Lafarge, V.; Girard, V.; Rault, A.; Maladen, V.; Gruss, A.; Leveau, J.-Y.; Delacroix-Buchet, A. Molecular fingerprinting of dairy microbial ecosystems by use of temporal temperature and denaturing gradient gel electrophoresis. Appl. Environ. Microbiol. 2004, 70, 5628-5643. [CrossRef] [PubMed]

2. Randazzo, C.L.; Vaughan, E.E.; Caggia, C. Artisanal and experimental Pecorino Siciliano cheese: Microbial dynamics during manufacture assessed by culturing and PCR-DGGE analyses. Int. J. Food Microbiol. 2006, 109, 1-8. [CrossRef] [PubMed]

3. Ricciardi, A.; Guidone, A.; Ianniello, R.G.; Cioffi, S.; Aponte, M.; Pavlidis, D.; Tsakalidou, E.; Zotta, T.; Parente, E. A survey of non-starter lactic acid bacteria in traditional cheeses: Culture dependent identification and survival to simulated gastrointestinal transit. Int. Dairy J. 2015, 43, 42-50. [CrossRef]

4. Beresford, T.P.; Fitzsimons, N.A.; Brennan, N.L.; Cogan, T.M. Recent advances in cheese microbiology. Int. Dairy J. 2001, 11, 259-274. [CrossRef]

5. Czerwińska, E.; Piotrowski, W. Potential sources of milk contamination influencing its quality for consumption. Rocz. Ochrona Środow. 2011, 13, 635-652. (in Polish).

6. Lawlor, J.; Delahunty, C.M.; Wilkinson, M.G.; Sheehan, J. Swiss-type and Swiss-cheddar hybrid-type cheeses: Effects of manufacture on sensory character and relationships between the sensory attributes and volatile compounds and gross compositional constituents. Int. J. Dairy Technol. 2003, 56, 39-51. [CrossRef]

7. Joux, F.; Lebaron, P. Use of fluorescent probes to assess physiological functions of bacteria at single-cell level. Microbes Infect. 2000, 2, 1523-1535. [CrossRef]

8. Dove, A. PCR: Thirty-five years and counting. Science 2018, 360, 670-672. [CrossRef]

9. Cocolin, L.; Mataragas, M.; Bourdichon, F.; Doulgeraki, A.; Pilet, M.-F.; Jagadeesan, B.; Rantsiou, K.; Phister, T. Next generation microbiological risk assessment meta-omics: The next need for integration. Int. J. Food Microbiol. 2018, 287, 3-9. [CrossRef]

10. Kergourlay, G.; Taminiau, B.; Daube, G.; Champomier Verges, M.C. Metagenomic insights into the dynamics of microbial communities in food. Int. J. Food Microbiol. 2015, 213, 31-39. [CrossRef]

11. Ercolini, D.; De Filippis, F.; La Storia, A.; Iacono, M. "Remake” by high-throughput sequencing of the microbiota involved in the production of water buffalo mozzarella cheese. Appl. Environ. Microbiol. 2012, 78, 8142-8145. [CrossRef] [PubMed]

12. Delcenserie, V.; Taminiau, B.; Delhalle, L.; Nezer, C.; Doyen, P.; Crevecoeur, S.; Roussey, D.; Korsak, N.; Daube, G. Microbiota characterization of a Belgian protected designation of origin cheese, Herve cheese, using metagenomic analysis. J. Dairy Sci. 2014, 97, 6046-6056. [CrossRef] [PubMed]

13. Dalmasso, A.; de los Dolores Soto del Rio, M.; Civera, T.; Pattono, D.; Cardazzo, B.; Bottero, M.T. Characterization of microbiota in Plaisentif cheese by high-throughput sequencing. LWT-Food Sci. Technol. 2016, 69, 490-496. [CrossRef]

14. De Filippis, F.; Genovese, A.; Ferranti, P.; Gilbert, J.A.; Ercolini, D. Metatranscriptomics reveals temperature-driven functional changes in microbiome impacting cheese maturation rate. Sci. Rep. 2016, 6, 21871. [CrossRef]

15. Escobar-Zepeda, A.; Sanchez-Flores, A.; Quirasco Baruch, M. Metagenomic analysis of a Mexican ripened cheese reveals a unique complex microbiota. Food Microbiol. 2016, 57, 116-127. [CrossRef]

16. Ceugniez, A.; Taminiau, B.; Coucheney, F.; Jacques, P.; Delcenserie, V.; Daube, G.; Drider, D. Use of a metagenetic approach to monitor the bacterial microbiota of "Tomme d'Orchies" cheese during the ripening process. Int. J. Food Microbiol. 2017, 247, 65-69. [CrossRef] 
17. Dugat-Bony, E.; Straub, C.; Teissandier, A.; Onesime, D.; Loux, V.; Monnet, C.; Irlinger, F.; Landaud, S.; Leclercq-Perlat, M.N.; Bento, P.; et al. Overview of a surface-ripened cheese community functioning by meta-omics analyses. PLoS ONE 2015, 10, e0124360. [CrossRef]

18. Porcellato, D.; Skeie, S.B. Bacterial dynamics and functional analysis of microbial metagenomes during ripening of Dutch-type cheese. Int. Dairy J. 2018, 61, 182-188. [CrossRef]

19. Duru, I.C.; Laine, P.; Andreevskaya, M.; Paulin, L.; Kananen, S.; Tynkkynen, S.; Auvinen, P.; Smolander, O.-P. Metagenomic and metatranscriptomic analysis of the microbial community in Swiss-type Maasdam cheese during ripening. Int. J. Food Microbiol. 2018, 281, 10-22. [CrossRef]

20. Albenzio, M.; Corbo, M.R.; Rehman, S.U.; Fox, P.F.; De Angelis, M.; Corsetti, A.; Sevi, A.; Gobbetti, M. Microbiological and biochemical characteristics of Canestrato Pugliese cheese made from raw milk, pasteurized milk or by heating the curd in hot whey. Int. J. Food Microbiol. 2001, 67, 35-48. [CrossRef]

21. Dahl, S.; Tavaria, F.K.; Malcata, F.X. Relationships between flavour and microbiological profiles in Serra da Estrela cheese throughout ripening. Int. Dairy J. 2000, 10, 255-262. [CrossRef]

22. Marini, M.; Maifreni, M.; Rondinini, G. Microbiological characterization of artisanal Montasio cheese: Analysis of its indigenous lactic acid bacteria. FEMS Microbiol. Lett. 2003, 229, 133-140. [CrossRef]

23. ISO 707:2008 (IDF 50:2008). Milk and Milk Products-Guidance on Sampling; International Standard Organization: London, UK, 2008.

24. ISO 3433:2008 (IDF 222: 2008). Cheese-Determination of Fat Content-Van Gulik Method; International Standard Organization: London, UK, 2008.

25. ISO 5943:2006 (IDF 88:2006). Cheese and Processed Cheese Products-Determination of Chloride Content-Potentiometric Titration Method; International Standard Organization: London, UK, 2006.

26. AOAC International 2005. Official Methods of Analysis, 18th ed.; AOAC International: Gaithersburg, MD, USA, 2005.

27. Klindworth, A.; Pruesse, E.; Schweer, T.; Schweer, T.; Peplies, J.; Quast, C.; Horn, M.; Glockner, F.O. Evaluation of general 16S ribosomal RNA gene PCR primers for classical and next-generation sequencing-based diversity studies. Nucleic Acids Res. 2013, 41, e1. [CrossRef] [PubMed]

28. Meyer, F.; Paarmann, D.; D'Souza, M.; Olson, R.; Glass, E.M.; Kubal, M.; Paczian, T.; Rodriguez, A.; Stevens, R.; Wilke, A.; et al. The metagenomics RAST server-a public resource for the automatic phylogenetic and functional analysis of metagenomes. BMC Bioinformatics 2008, 9, 386-394. [CrossRef] [PubMed]

29. Aljewicz, M.; Cichosz, G. Influence of probiotic (Lactobacillus acidophilus NCFM, L. paracasei LPC37, and L. rhamnosus HN001) strains on starter cultures and secondary microbiota in Swiss-and Dutch-type cheeses. J. Food Process. Preserv. 2017, 41, e13253. [CrossRef]

30. de Souza, C.F.V.; Dalla Rosa, T.; Ayub, M.A.Z. Changes in the microbiological and physicochemical characteristics of Serrano cheese during manufacture and ripening. Braz. J. Microbiol. 2003, 34, 260-266. [CrossRef]

31. Park, W.; Yoo, J.; Oh, S.; Ham, J.S.; Jeong, S.G.; Kim, Y. Microbiological characteristics of Gouda cheese manufactured with pasteurized and raw milk during ripening using next generation sequencing. Food Sci. Animal Resource 2019, 39, 585-600. [CrossRef]

32. Van Hoorde, K.; Heyndrickx, M.; Vandamme, P.; Huys, G. Influence of pasteurization, brining conditions and production environment on the microbiota of artisan Gouda-type cheeses. Food Microbiol. 2010, 27, 425-433. [CrossRef]

33. Martín-Platero, A.M.; Maqueda, M.; Valdivia, E.; Purswani, J.; Martínez-Bueno, M. Polyphasic study of microbial communities of two Spanish farmhouse goats' milk cheeses from Sierra de Aracena. Food Microbiology 2009, 6, 294-304. [CrossRef]

34. Sánchez-Gamboa, C.; Hicks-Pérez, L.; Gutiérrez-Méndez, N.; Heredia, N.; García, S.; Nevárez-Moorillón, G. Microbiological changes during ripening of Chihuahua cheese manufactured with raw milk and its seasonal variations. Foods 2018, 7, 153. [CrossRef]

35. Bermúdez, J.; González, M.J.; Olivera, J.A.; Burgueño, J.A.; Juliano, P.; Fox, E.M.; Reginensi, S.M. Seasonal occurrence and molecular diversity of clostridia species spores along cheesemaking streams of 5 commercial dairy plants. J. Dairy Sci. 2016, 99, 3358-3366. [CrossRef] [PubMed]

36. Matijasic, B.B.; Rajsp, M.K.; Perko, B.; Rogelj, I. Inhibition of Clostridium tyrobutyricum in cheese by Lactobacillus gasseri. Int. Dairy J. 2007, 17, 157-166. [CrossRef] 
37. Alegria, A.; Szczęsny, P.; Mayo, B.; Bardowski, J.; Kowalczyk, M. Biodiversity in Oscypek, a traditional Polish cheese, determined by culture-dependent and -independent approaches. Appl. Environ. Microbiol. 2012, 78, 1890-1898. [CrossRef] [PubMed]

38. Fernandes, T.J.R.; Oliveira, M.B.P.P.; Mafra, I. Tracing transgenic maize as affected by breadmaking process and raw material for the production of a traditional maize bread, broa. Food Chem. 2013, 138, 687-692. [CrossRef] [PubMed]

39. Cichosz, G.; Szpendowski, J.; Cichosz, A.J.; Kornacki, M. Paracasein degradation in gouda cheeses produced with Lactobacillus culture. ŻYWNOŚĆ. Nauka. Technologia. Jakość 2006, 1, 58-65, (in Polish, abstract in English).

40. Czaran, T.; Rattray, F.P.; Møller, C.O.A.; Christensen, B.B. Modelling the influence of metabolite diffusion on non-starter lactic acid bacteria growth in ripening Cheddar cheese. Int. Dairy J. 2018, 80, 35-45. [CrossRef]

41. Alessandria, V.; Ferrocino, I.; De Filippis, F.; Fontana, M.; Rantsiou, K.; Ercolini, D.; Cocolin, L. Microbiota of an Italian Grana-like cheese during manufacture and ripening, unraveled by $16 \mathrm{~S}$ rRNA-based approaches. Appl. Environ. Microbiol. 2016, 82, 3988-3995. [CrossRef]

42. Almeida, M.; Hébert, A.; Abraham, A.-L.; Rasmussen, S.; Monnet, C.; Pons, N.; Delbès, C.; Loux, V.; Batto, J.-M.; Leonard, P.; et al. Construction of a dairy microbial genome catalog opens new perspectives for the metagenomic analysis of dairy fermented products. BMC Genomics 2014, 15, 1101-1117. [CrossRef]

43. Klijn, N.; Nieuwenhof, F.F.J.; Hoolwerf, J.D.; van der Waals, C.B.; Weerkamp, A.H. Identification of Clostridium tyrobutyricum as the causative agent of late blowing in cheese by species-specific PCR amplification. Appl. Environ. Microbiol. 1995, 61, 2919-2924. [CrossRef]

44. Bassi, D.; Puglisi, E.; Cocconcelli, P.S. Understanding the bacterial communities of hard cheese with blowing defect. Food Microbiol. 2015, 52, 106-118. [CrossRef]

45. Henderson, G.; Cox, F.; Ganesh, S.; Jonker, A.; Young, W.; Global Rumen Census Collaborators; Janssen, P.H. Rumen microbial community composition varies with diet and host, but a core microbiome is found across a wide geographical range. Sci. Rep. 2015, 5, 14567. [CrossRef] [PubMed]

46. Jami, E.; Mizrahi, I. Similarity of the ruminal bacteria across individual lactating cows. Anaerobes 2012, 18, 338-343. [CrossRef] [PubMed]

47. Goodfellow, M.; Jones, A.L. Laceyella. Bergey's Man. Syst. Arch. Bact. 2015. [CrossRef]

48. Brooke, C.J.; Riley, T.V. Erysipelothrix rhusiopathiae: Bacteriology, epidemiology and clinical manifestations of an occupational pathogen. J. Medical Microbiol. 1999, 48, 789-799. [CrossRef]

49. Bokulich, N.A.; Mills, D.A. Facility-specific "house" microbiome drives microbial landscapes of artisan cheesemaking plants. Appl. Environ. Microbiol. 2013, 79, 5214-5223. [CrossRef] [PubMed] 